\title{
Characterisation of Prosopis juliflora Seed Gum and the Effect of its Addition to $\kappa$-Carrageenan Systems
}

\author{
Edwin G. Azero ${ }^{a}$ and Cristina T. Andrade ${ }^{*, b}$ \\ ${ }^{a}$ Departamento de Ciências Naturais (ECB), Universidade Federal do Estado do Rio de Janeiro, \\ Av. Pasteur, 458, 22290-240 Rio de Janeiro-RJ, Brazil \\ ${ }^{b}$ Instituto de Macromoléculas Professora Eloisa Mano, Universidade Federal do Rio de Janeiro, \\ CP 68525, 21945-970 Rio de Janeiro-RJ, Brazil
}

\begin{abstract}
A galactomanana de Prosopis juliflora (PJ) foi obtida por extração em água, a $50{ }^{\circ} \mathrm{C}$, a partir de sementes moídas. As suas características estruturais e as propriedades em solução foram comparadas com as de uma amostra comercial de goma guar (GG). Após degradação parcial, as amostras resultantes foram submetidas à espectroscopia de ${ }^{13} \mathrm{C} R \mathrm{RN}$. As razões manose/galactose de $\mathrm{PJ}(\mathrm{M} / \mathrm{G}=1,64)$ e de $\mathrm{GG}(\mathrm{M} / \mathrm{G}=1,85)$ foram determinadas a partir das áreas relativas aos picos atribuídos a C-1. A expansão das linhas do C-4 revelaram diferenças na estrutura fina das duas galactomananas. A viscosidade intrínseca determinada para a amostra de $\mathrm{GG},[\eta]=10,3 \mathrm{dL}$ $\mathrm{g}^{-1}$, foi ligeiramente maior do que a determinada para a PJ, $[\eta]=9,4 \mathrm{dL} \mathrm{g}^{-1}$. Experimentos dinâmicos realizados nas mesmas concentrações mostraram comportamentos viscoelásticos similares para as duas gomas. Nenhum aumento no módulo de armazenamento $\left(\mathrm{G}^{\prime}\right)$ foi observado para misturas $\kappa$-carragenana/PJ em $0,1 \mathrm{~mol} \mathrm{~L}^{-1} \mathrm{KCl}$ em uma concentração total de $1,0 \mathrm{~g} \mathrm{~L}^{-1}$, em relação à $\kappa$-carragenana sozinha. Géis fortes, obtidos pela mistura de $\kappa$-carragenana e PJ ou GG em 0,25 mol L ${ }^{-1} \mathrm{KCl}$ em uma concentração total de $10 \mathrm{~g} \mathrm{~L}^{-1}$ apresentaram propriedades mecânicas similares.
\end{abstract}

The galactomannan from Prosopis juliflora (PJ galactomannan) was extracted from milled seeds in water at $50{ }^{\circ} \mathrm{C}$. Its structural and solution properties were characterised in comparison with a commercial sample of guar gum (GG galactomannan). After partial degradation, the resulting samples were submitted to ${ }^{13} \mathrm{C}-\mathrm{NMR}$ spectroscopy. The mannose to galactose (M/G) ratios of PJ $(\mathrm{M} / \mathrm{G}=1.64)$ and $\mathrm{GG}(\mathrm{M} / \mathrm{G}=1.85)$ galactomannans were estimated from the relative peak areas of the corresponding C-1 lines. Expansion of the C-4 lines revealed differences in the fine structure of the two galactomannans. The intrinsic viscosity determined for the GG sample, $[\eta]=10.3 \mathrm{dL}$ $\mathrm{g}^{-1}$, was slightly higher than that determined for PJ galactomannan, $[\eta]=9.4 \mathrm{dL} \mathrm{g}^{-1}$. Dynamic experiments carried out at the same concentrations showed similar viscoelastic behaviours for the two gums. No enhancement in the storage modulus $\left(\mathrm{G}^{\prime}\right)$ was observed for $\kappa$-carrageenan/PJ mixed solution in $0.1 \mathrm{~mol} \mathrm{~L}^{-1} \mathrm{KCl}$ at $1.0 \mathrm{~g} \mathrm{~L}^{-1}$ total polymer concentration, in relation to $\kappa$-carrageenan alone. Self-supporting gels obtained by mixing $\kappa$-carrageenan and PJ or GG galactomannans in $0.25 \mathrm{~mol} \mathrm{~L}^{-1} \mathrm{KCl}$ at $10 \mathrm{~g} \mathrm{~L}^{-1}$ total polymer concentration displayed similar mechanical properties.

Keywords: rheology, galactomannan, structural characterisation, Prosopis juliflora, $\kappa$ carrageenan

\section{Introduction}

Galactomannans are non-gelling polysaccharides, commercially important mainly for their thickening properties. They occur as storage material in the seed endosperm of certain leguminous trees and shrubs. These polysaccharides consist of a linear chain of $(1,4)$-linked $\beta$-D-mannose residues, substituted with $\alpha$-D-galactose

*e-mail: ctandrade@ima.ufrj.br single units at the O-6 position of the mannan main chain. The molecular weight, the mannose to galactose ratio $(\mathrm{M} / \mathrm{G})$ and the sequential distribution of the galactose substituents depend on their source.

Food and technological applications have encouraged investigations on mixed systems, particularly those consisting of xanthan gum and locust bean gum (LBG), the galactomannan from Ceratonia siliqua seeds with a high M/G ( 4:1) and non-regular D-galactose distribution. ${ }^{1}$ The addition of LBG to xanthan gum, a non-gelling 
microbial polysaccharide, causes a significant increase in viscosity at low concentrations. At higher concentrations, thermoreversible gels are formed..$^{2-4}$ The addition of LBG to $\kappa$-carrageenan or agarose, gelling polysaccharides extracted from seaweeds, is known to give gels at concentrations below the minimum required for $\kappa$-carrageenan or agarose alone. Compared to $\kappa$-carrageenan or agarose gels at the same concentration, the mixed gels with LBG present increased gel strength and elasticity, and a reduced tendency toward syneresis. . $^{2,5,6}$

Such synergic interactions observed with LBG were found to decrease in magnitude when other galactomannans with higher galactose contents were considered. ${ }^{2}$ However, experimental data have shown that guar gum (GG), the galactomannan from Cyamopsis tetragonolobus seeds with a $\mathrm{M} / \mathrm{G}$ of approximately $2: 1$, is effective in producing an increase in viscosity when blended with xanthan gum. ${ }^{3,7-9}$ Viscoelastic measurements of xanthan gum mixtures with GG samples of different molecular weights showed a significant effect of molecular weight; the higher the molecular weight, the stronger the effect. ${ }^{10}$ At high extents of enzymatic modification, GG was shown to interact synergically with xanthan to produce gels with elastic modulus and yield stress similar to or exceeding those of locust bean gum. ${ }^{11}$ In mixtures with $\kappa$-carrageenan ${ }^{12}$ and agarose, ${ }^{13} \mathrm{GG}$ was found to play a role in the gelation process of the mixed systems.

In the present work, the galactomannan from Prosopis juliflora seeds (PJ) was characterised in terms of structural and rheological properties and compared to GG. Mixed solutions and gels of PJ and GG galactomannans with $\kappa$-carrageenan were studied by viscoelastic and uniaxial compression experiments.

More than 40 species of Prosopis are reported to be distributed around the world in arid and semiarid regions. ${ }^{14}$ Prosopis juliflora was introduced in northeastern Brazil in the forties. Since then, its pods have been used mainly as animal feed. ${ }^{15}$ The physicochemical characterisation and in vitro digestibility and colonic fermentability of PJ samples from Peru, obtained by acid and roasting processes, were investigated. The gum was proven to be indigestible and recommended as a soluble dietary fibre. ${ }^{14}$

\section{Experimental}

\section{Materials}

Seeds of Prosopis juliflora were supplied by Supranor Indústria e Comércio Ltda, Recife, Brazil. GG was purchased from Dowell Schumberger and purified as described below for the galactomannan from Prosopis juliflora. A sample of $\kappa$-carrageenan, with intrinsic viscosity of $9.68 \mathrm{dL} \mathrm{g}^{-1}$ in $0.1 \mathrm{~mol} \mathrm{~L}^{-1} \mathrm{NaCl}$ at $25^{\circ} \mathrm{C}$ and $24.5 \%(\mathrm{~m} / \mathrm{m})$ sulfate content, was obtained as sodium salt from Hypnea musciformis, according to the procedure described elsewhere. ${ }^{16}$

\section{Extraction procedures}

Seeds of Prosopis juliflora were milled and submitted to lipid extraction with toluene: ethyl alcohol (2:1) mixture in a Soxhlet, for $24 \mathrm{~h}$. After drying, enzyme inactivation was achieved by boiling in water for $8 \mathrm{~min}$. Galactomannan extraction was carried out at $50{ }^{\circ} \mathrm{C}$ under stirring for $1 \mathrm{~h}$. The crude mixture, containing pieces of hull, germ and the galactomannan solution, was filtered and centrifuged at $5000 \mathrm{rpm}$ for $3 \mathrm{~h}$. The polymer (PJ galactomannan) was recovered by precipitation in ethyl alcohol, filtered, dried at $40{ }^{\circ} \mathrm{C}$ for 2-3 days, and milled.

\section{Moisture, ash and protein contents}

The moisture and ash contents of the PJ galactomannan were determined according to ASTM-D1439-72 and ASTM-D-1347-72, respectively. The Kjeldahl method was used to quantify the total nitrogen content; the conversion factor of 5.87 was used to calculate protein content.

\section{${ }^{13} \mathrm{C}$ NMR spectrometry}

Galactomannan solutions at $1 \mathrm{~g} \mathrm{~L}^{-1}$ concentration were sonicated for $12 \mathrm{~h}$. The partially degraded products were recovered by freeze-drying. ${ }^{13} \mathrm{C}$ NMR spectra were obtained in $\mathrm{D}_{2} \mathrm{O}$ solution with a Bruker AM 300 spectrometer, operating at a ${ }^{13} \mathrm{C}$ frequency of $75.4 \mathrm{MHz}$. A $75^{\circ}$ pulse and a repetition time of $0.95 \mathrm{~s}$ were applied. Spectra were recorded at $80{ }^{\circ} \mathrm{C}$ under conditions of inverse gated decoupling. Peak areas were measured with a planimeter.

\section{Preparation of solutions}

Galactomannan solutions were prepared by dispersing a determined amount of polymer in distilled and deionised water with stirring at room temperature overnight. Further dilutions were made to obtain a wide range of solution concentrations. $\kappa$-Carrageenan solutions were prepared by stirring the required weight of polymer in $0.1 \mathrm{~mol} \mathrm{~L}^{-1} \mathrm{KCl}$ (viscoelastic tests) or $0.25 \mathrm{~mol} \mathrm{~L}^{-1} \mathrm{KCl}$ (compression tests) at $70{ }^{\circ} \mathrm{C}$ for $1 \mathrm{~h}$ and at $90^{\circ} \mathrm{C}$ for $15 \mathrm{~min} . \kappa$-Carrageenan/PJ galactomannan solutions were prepared by mixing the required weight of the polymers before adding the solvent. The same thermal treatment applied to $\kappa$-carrageenan 
alone was used to prepare the mixed solutions. Selfsupporting gels were prepared by pouring the hot solutions into glass moulds of $200 \mathrm{~mm}$ height and $20 \mathrm{~mm}$ diameter. After gelation, the gels were cut into five cylindric specimens, which were aged in $0.25 \mathrm{~mol} \mathrm{~L}^{-1} \mathrm{KCl}$ at $15^{\circ} \mathrm{C}$ for $20 \mathrm{~h}$. The gels specimens were conditioned at $25{ }^{\circ} \mathrm{C}$ for $4 \mathrm{~h}$ before performing the tests.

\section{Solution properties}

Viscosity measurements were carried out at $25{ }^{\circ} \mathrm{C}$ in a Contraves Low Shear 40 rheometer, equipped with coaxial cylinders of MS-DIN 412 geometry, within the shear rate range from $10^{-1}$ to $10^{2} \mathrm{~s}^{-1}$.

To determine the intrinsic viscosity, $[\eta]$, a galactomannan solution at $0.5 \mathrm{~g} \mathrm{~L}^{-1}$ was prepared at room temperature overnight and centrifuged at $5000 \mathrm{rpm}$ for $1 \mathrm{~h}$. The supernatant was used for further dilutions. Relative viscosities in the range 1.2 to 2.0 were considered for the combined extrapolation of Huggins and Kraemer, expressed by equations 1 and 2, respectively.

$\eta_{\mathrm{sp}} / \mathrm{C}=[\eta]+\mathrm{k}_{\mathrm{H}}[\eta]^{2} \mathrm{C}$

$\left(\ln \eta_{\mathrm{r}}\right) / \mathrm{C}=[\eta]+\mathrm{k}_{\mathrm{K}}[\eta]^{2} \mathrm{C}$

Viscosity average molecular weights, $\overline{\mathrm{M}}_{\mathrm{v}}$, were calculated by equation 3, the Mark-Houwink equation given by Doublier and Launay ${ }^{17}$ for guar gum and modified by Gaisford et al., ${ }^{18}$

$[\eta]=11.55 \times 10^{-6}\left[(1-r) \bar{M}_{v}\right]^{0.98}$

where $r$ is the galactose/(mannose + galactose) ratio and $[\eta]$ is the intrinsic viscosity, in $\mathrm{dL} \mathrm{g}^{-1}$.

Galactomannan solutions at 5,8 and $10 \mathrm{~g} \mathrm{~L}^{-1}$ were submitted to steady and oscillatory measurements at $25^{\circ} \mathrm{C}$ in a Haake RheoStress RS100, equipped with a cone and plate geometry $\left(4^{\circ}\right.$ cone angle, $35 \mathrm{~mm}$ diameter, 0.105 mm gap). Steady shear measurements were carried out over the shear rate range of 0.1 to $720 \mathrm{~s}^{-1}$. Dynamic measurements were performed over the range of $10^{-2}$ to $10^{2} \mathrm{rad} \mathrm{s}^{-1}$, with the strain amplitude fixed at $2 \%$ to assure working conditions inside the linear viscoelastic region.

\section{Mechanical measurements of self-supporting gels}

The mechanical properties of $\kappa$-carrageenan alone, $\kappa$ carrageenan/PJ and $\kappa$-carrageenan/GG mixed gels were determined by compression experiments at $5 \mathrm{~mm} \mathrm{~min}{ }^{-1}$ and $25{ }^{\circ} \mathrm{C}$, using an Instron Universal Testing Machine model 4204, equipped with a $1 \mathrm{kN}$ compression cell. The average value from a total of five measurements was taken. Young's modulus, E, was determined as

$\mathrm{E}=\frac{\mathrm{L}_{\circ}}{\mathrm{A}_{\mathrm{o}}} \frac{\Delta F}{\Delta L}$

where $\mathrm{L}_{\mathrm{o}}$ is the initial height and $\mathrm{A}_{\mathrm{o}}$ is the initial crosssection of the probe, and $\frac{\Delta F}{\Delta L}$ is the initial slope of the stress versus deformation curve.

\section{Results and Discussion}

The extraction process used in the present work is particularly useful for laboratory experiments, although other methods are preferred on an industrial scale. A high power mill should be employed to process galactomannan seeds. Although the extraction of the PJ galactomannan had been carried out at other temperatures for different periods of time, polymer yields were similar in all cases.

The dry PJ gum, recovered from solution by precipitation in ethyl alcohol had moisture, ash and protein contents of $8.9,0.38$ and $0.58 \%$, respectively.

High resolution ${ }^{13} \mathrm{C}$ NMR spectroscopy has already been used to determine the distribution of $(1 \rightarrow 6)$-linked $\alpha$-Dgalactopyranosyl side-groups along the $(1 \rightarrow 4)-\beta$-D-mannan main chain in galactomannans. ${ }^{19-22}$ Figure 1 shows the ${ }^{13} \mathrm{C}$ NMR spectra obtained for the partially degraded PJ and GG samples. The resonances of the carbon atoms are well resolved and the assignment of the peaks could be made according to the literature. Partially resolved peaks were observed for the C-1 mannan absorption in the guar gum spectrum. These absorptions have been assigned to nonsubstituted and substituted residues..$^{21}$ In the case of PJ gum, the $\mathrm{C}-1$ mannan peak shows a discrete shoulder in the region corresponding to the absorption of the non-substituted residue. The $\mathrm{M} / \mathrm{G}$ ratios were estimated from the relative peak areas of the corresponding $\mathrm{C}-1$ lines as $\mathrm{M} / \mathrm{G}=1.64$ for the $\mathrm{PJ}$ sample and $\mathrm{M} / \mathrm{G}=1.85$ for the $\mathrm{GG}$ commercial sample. The result obtained for the PJ galactomannan is slightly higher than the $\mathrm{M} / \mathrm{G}$ ratio determined as 1.39 after acid hydrolysis of the raw endosperm and gas chromatography analysis of the alditol acetate derivatives. ${ }^{14}$

The region corresponding to $\mathrm{C}-4$ of the D-mannose residues shows typical splitting. The expanded lines are shown in Figure 2. In the case of GG (trace B), three wellresolved peaks can be observed. This pattern of lines was explained by assuming that the $\mathrm{C}-4$ resonance is sensitive to whether or not the preceding residue in the chain is branched, ${ }^{19}$ and allows the determination of the diad frequencies (F). Peak I at lower field arises from diads in 


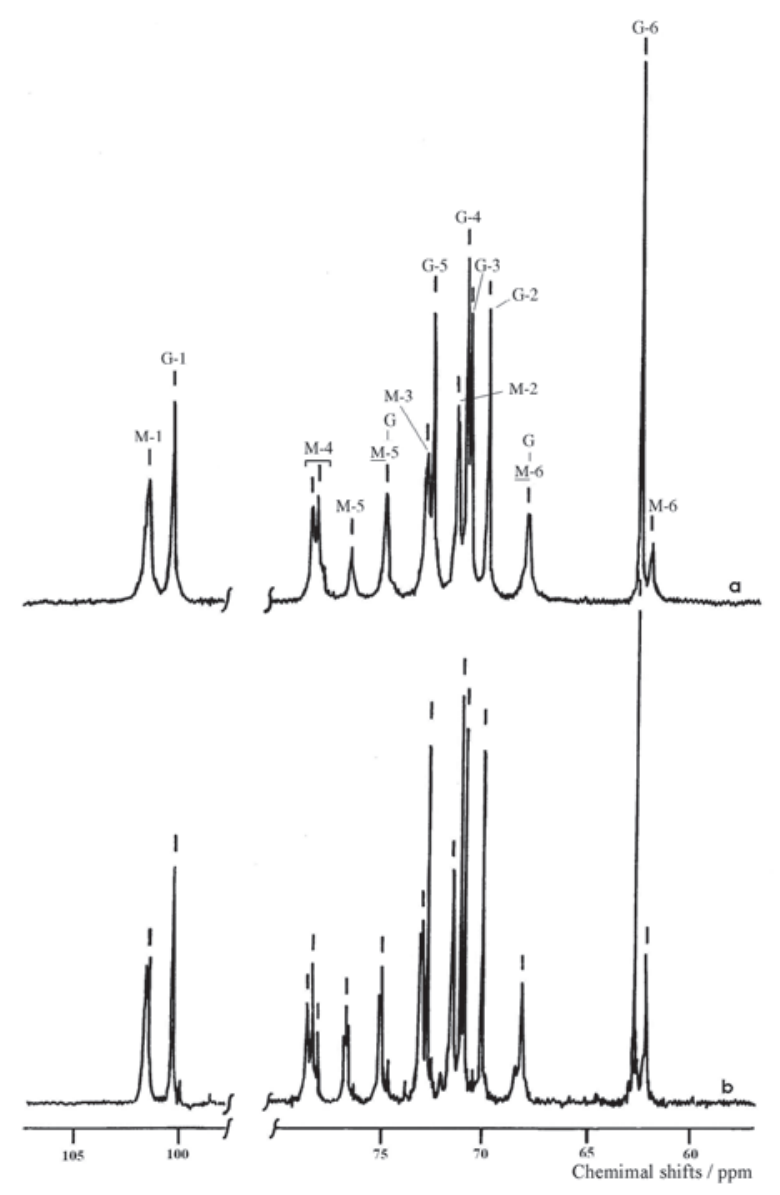

Figure 1. ${ }^{13} \mathrm{C}$ NMR spectra of partially degraded PJ (trace a) and GG (trace b) galactomannans; M - mannose, $\mathrm{G}$ - galactose residues.

which both D-mannose residues are substituted. Peak II originates from diads with only one substituent, and peak III from two adjoining unsubstituted D-mannose residues. The nearest-neighbour probabilities determined by integrating the three peaks are listed in Table 1. These data reveal that major segments of both galactomannan macromolecules are composed of diads with substituted and unsubstituted mannose repeating units and of diads with totally substituted mannose units. The higher degree of D-galactosyl side groups in the PJ galactomannan is evidenced by the lower intensity of the peak III. No splitting of the C-6 resonances was observed under the conditions used in the present experiments, as reported previously for galactomannans from other sources..$^{21,22}$

Table 1. Diad frequencies for the PJ and GG galactomanns

\begin{tabular}{lccc}
\hline Galactomannan & \multicolumn{3}{c}{ Diad frequencies $^{\mathrm{a}}$} \\
& $\mathrm{F}_{11}$ & $\mathrm{~F}_{12}=\mathrm{F}_{21}$ & $\mathrm{~F}_{22}$ \\
\hline $\mathrm{PJ}$ & 0.30 & 0.32 & 0.06 \\
$\mathrm{GG}$ & 0.23 & 0.32 & 0.13 \\
\hline
\end{tabular}

a Subscripts 1 and 2 refer to branched and unbranched D-mannose residues, respectively.

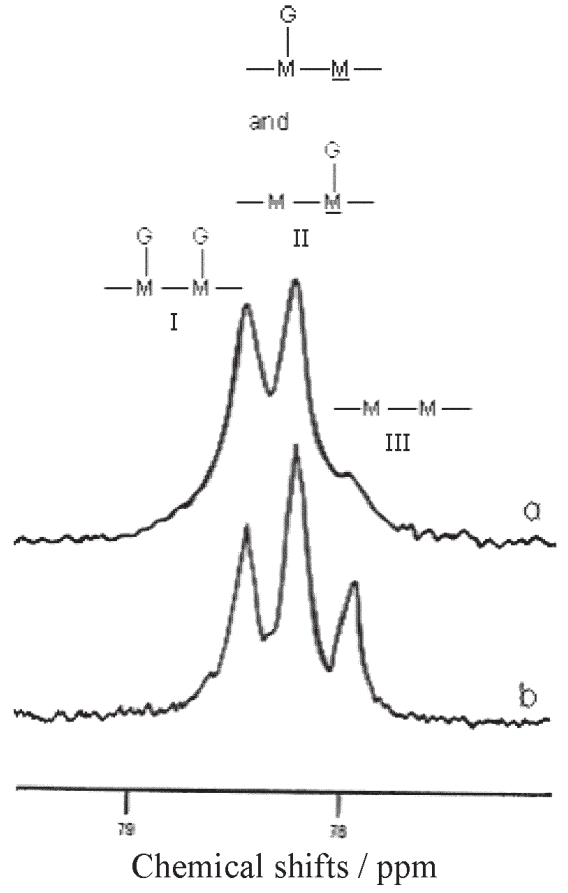

Figure 2. ${ }^{13} \mathrm{C}$ NMR region of C-4 of D-mannose residues of PJ (trace a) and GG (trace b) galactomannans; $\mathrm{M}$ - D-mannose, $\underline{\mathrm{M}}$ - D-mannose unit being considered; G - D-galactose.

Flow curves ( $\log \eta_{\mathrm{r}}$ plotted against $\log \dot{\gamma}$ ) obtained with the Low Shear 40 equipment for PJ water solutions (1.2 to $10 \mathrm{~g} \mathrm{~L}^{-1}$ ) are shown in Figure 3. Under the experimental conditions used, a Newtonian behaviour is observed for solutions of concentrations lower than $1.5 \mathrm{~g} \mathrm{~L}^{-1}$. The intrinsic viscosities, $[\eta]_{\mathrm{H}}=9.4 \mathrm{dL} \mathrm{g}^{-1}$ and $[\eta]_{\mathrm{K}}=9.7 \mathrm{dL} \mathrm{g}^{-1}$ were determined according to the Huggins' and Kramer's equations, respectively. For comparison, the intrinsic viscosities of the purified GG were also determined as $[\eta]_{\mathrm{H}}$ $=10.3 \mathrm{dL} \mathrm{g} \mathrm{g}^{-1}$ and $[\eta]_{\mathrm{K}}=10.8 \mathrm{dL} \mathrm{g}^{-1}$. These values are in accordance with that recently reported for $\mathrm{GG}^{23}$.

The physical chemical parameters, including the viscosity average molecular weights ( $\overline{\mathrm{M}}_{\mathrm{v}}$ ) calculated by equation 3 using the intrinsic viscosity values obtained by the Huggins' extrapolation, are summarized in Table 2. The $[\eta]$ and $\bar{M}_{v}$ values, as well as the $M / G$ ratio, were slightly higher for the GG galactomannan sample.

Table 2. Physical chemical parameters obtained for PJ and GG galactomannan samples

\begin{tabular}{lcc}
\hline & $\mathrm{PJ}$ & $\mathrm{GG}$ \\
\hline $\mathrm{M} / \mathrm{G}^{\mathrm{a}}$ & 1.64 & 1.85 \\
Intrinsic viscosity $\left(\mathrm{dL} \mathrm{g}^{-1}\right)$ & & \\
Huggins' extrapolation & 9.4 & 10.3 \\
$\overline{K r a e m e r}^{\prime}$ extrapolation & 9.7 & 10.8 \\
$\mathrm{M}_{\mathrm{v}} \times 10^{6}$ & 1.73 & 1.81 \\
\hline
\end{tabular}

${ }^{\mathrm{a}}$ Determined by ${ }^{13} \mathrm{C}$ NMR. 


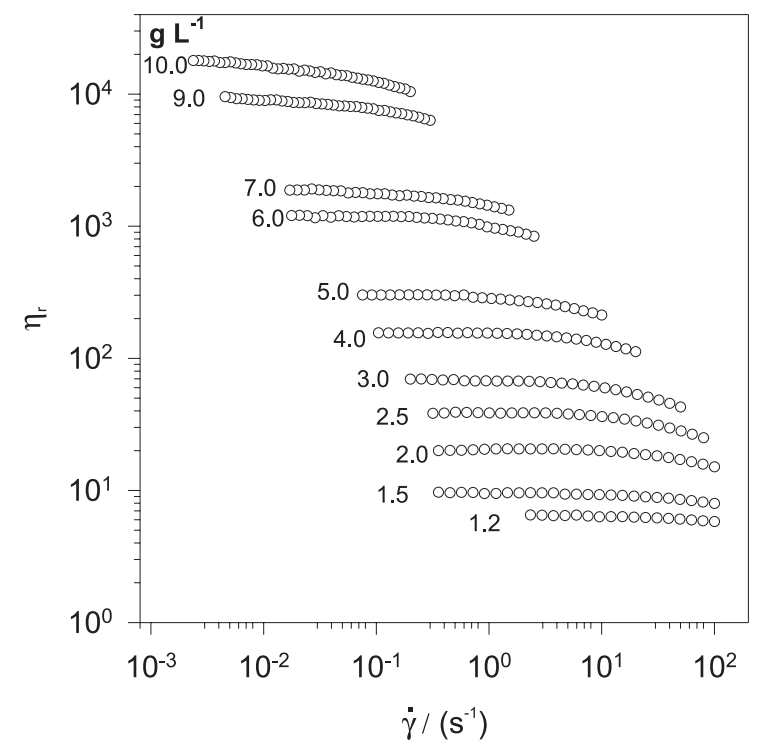

Figure 3. Relative viscosity $\left(\eta_{\mathrm{r}}\right)$ as a function of shear rate $(\dot{\gamma})$ for PJ galactomannan solutions in water at $25{ }^{\circ} \mathrm{C}$ (low shear rheometer).

The frequency dependence of the dynamic storage modulus $\left(\mathrm{G}^{\prime}\right)$ and loss modulus $\left(\mathrm{G}^{\prime \prime}\right)$ for PJ and GG solutions at 5, 8 and $10 \mathrm{~g} \mathrm{~L}^{-1}$ concentrations are illustrated in Figures $4 \mathrm{a}$ and $4 \mathrm{~b}$. The behaviour observed for both galactomannans at 5 and $8 \mathrm{~g} \mathrm{~L}^{-1}$ is typical of macromolecular solutions, with $G^{\prime \prime}>G^{\prime}$ along the frequency range studied. For solutions at $10 \mathrm{~g} \mathrm{~L}^{-1}$ concentration, the cross-over of $\mathrm{G}^{\prime}$ and $\mathrm{G}^{\prime \prime}$ was detected at high frequency. For the GG solution, the cross-over point is reached at a lower frequency. In general, the values of $\mathrm{G}^{\prime}$ and $\mathrm{G}^{\prime \prime}$ are higher for $\mathrm{GG}$ solutions, which is in accordance with the results obtained from viscosity measurements.

In Figure 5, solution properties under steady and oscillatory shear are compared for PJ and GG solutions in water, at concentrations of 5 and $10 \mathrm{~g} \mathrm{~L}^{-1}$. These experiments were carried out in a Haake RheoStress RS100 rheometer over a wider shear rate range and show part of the Newtonian plateau and the shear-thinning region of the solutions. When the same numerical values of the shear rate $(\dot{\gamma})$ and frequency $(\omega)$ are considered, the $\dot{\gamma}$ dependence of the viscosity $(\eta)$ and the $\omega$ dependence of the complex viscosity $\left(\eta^{*}\right)$ are closely superimposable for both galactomannan solutions, which means that the Cox-Merz rule was satisfactorily followed, ${ }^{24}$ as previously observed for other galactomannans from non-conventional sources. ${ }^{25}$

The effect of the addition of the PJ galactomannan to $\kappa$-carrageenan solutions was investigated. The $\kappa$ carrageenan sample was obtained from Hypnea musciformis and purified as the sodium salt form. $\kappa$-Carrageenan
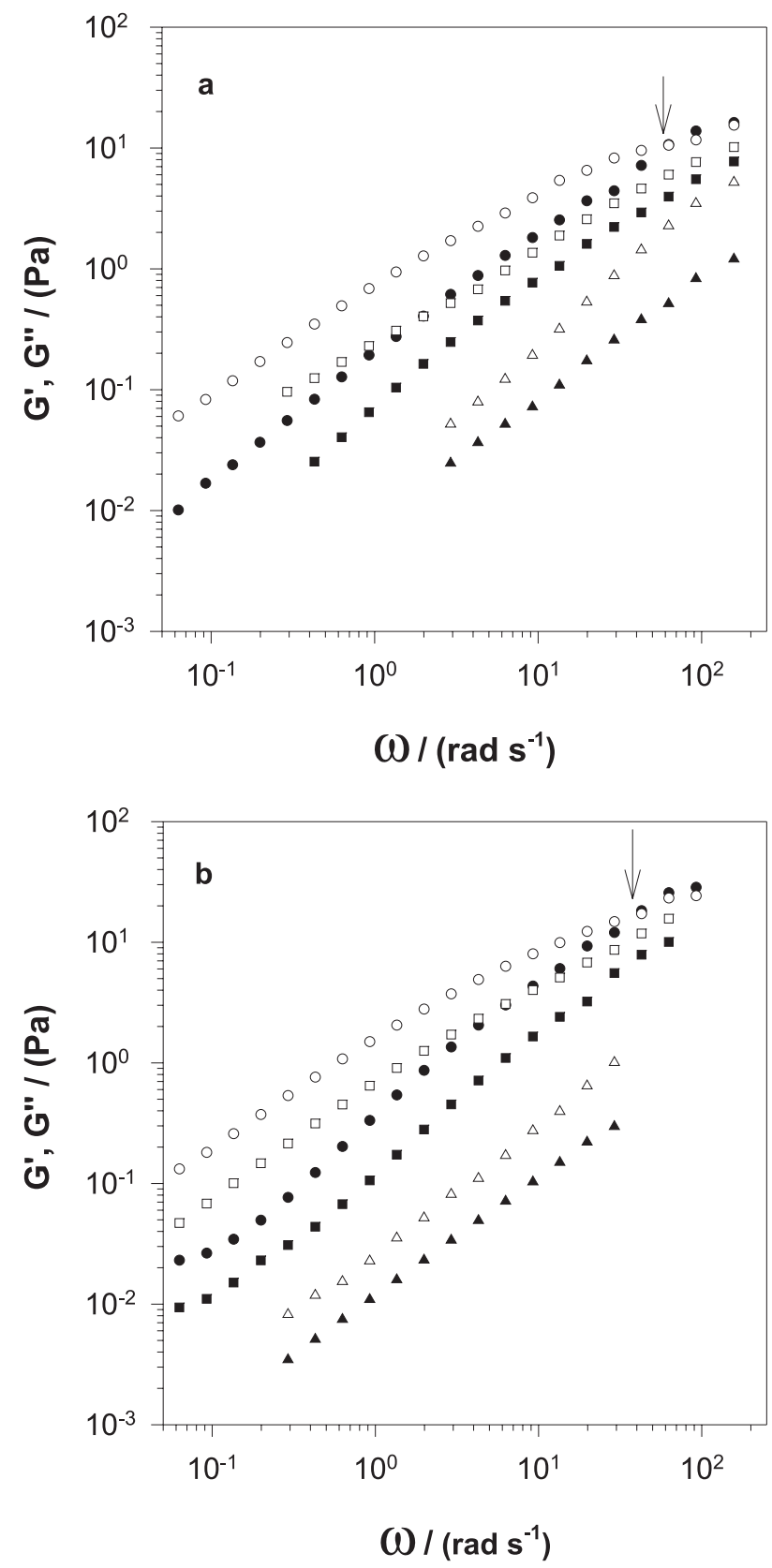

Figure 4. Frequency sweep of galactomannan solutions at $25^{\circ} \mathrm{C}$ and $\mathrm{C}=$ $5 \mathrm{~g} \mathrm{~L}^{-1}\left(\boldsymbol{\Delta}, \mathrm{G}^{\prime} ; \triangle, \mathrm{G}^{\prime \prime}\right), \mathrm{C}=8 \mathrm{~g} \mathrm{~L}^{-1}\left(\boldsymbol{\square}, \mathrm{G}^{\prime} ; \square, \mathrm{G}^{\prime \prime}\right)$ and $\mathrm{C}=10 \mathrm{~g} \mathrm{~L}^{-1}\left(\boldsymbol{\bullet}, \mathrm{G}^{\prime}\right.$; $\mathrm{O}, \mathrm{G}^{\prime \prime}$ ); (a) PJ solutions, (b) GG solutions (controlled-stress rheometer).

solutions in $0.1 \mathrm{~mol} \mathrm{~L}^{-1} \mathrm{KCl}$ at different polymer concentrations and $25^{\circ} \mathrm{C}$ were submitted to oscillatory shear in the Low Shear 40 rheometer. Figure 6 shows the frequency dependence of $\mathrm{G}^{\prime}$ and $\mathrm{G}^{\prime \prime}$ for $\kappa$-carrageenan solutions at 1.0 and $1.2 \mathrm{~g} \mathrm{~L}^{-1}$ and for $3: 1 \kappa$-carrageenan/PJ galactomannan mixed solutions at $1.0 \mathrm{~g} \mathrm{~L}^{-1}$ total polymer concentration. For $\kappa$-carrageenan solutions at concentrations lower than $1.2 \mathrm{~g} \mathrm{~L}^{-1}$, the viscoelastic behaviour was typical of a macromolecular solution, with $\mathrm{G}^{\prime \prime}>\mathrm{G}^{\prime}$ throughout the frequency range studied. At $1.2 \mathrm{~g} \mathrm{~L}^{-1}$, the mechanical 


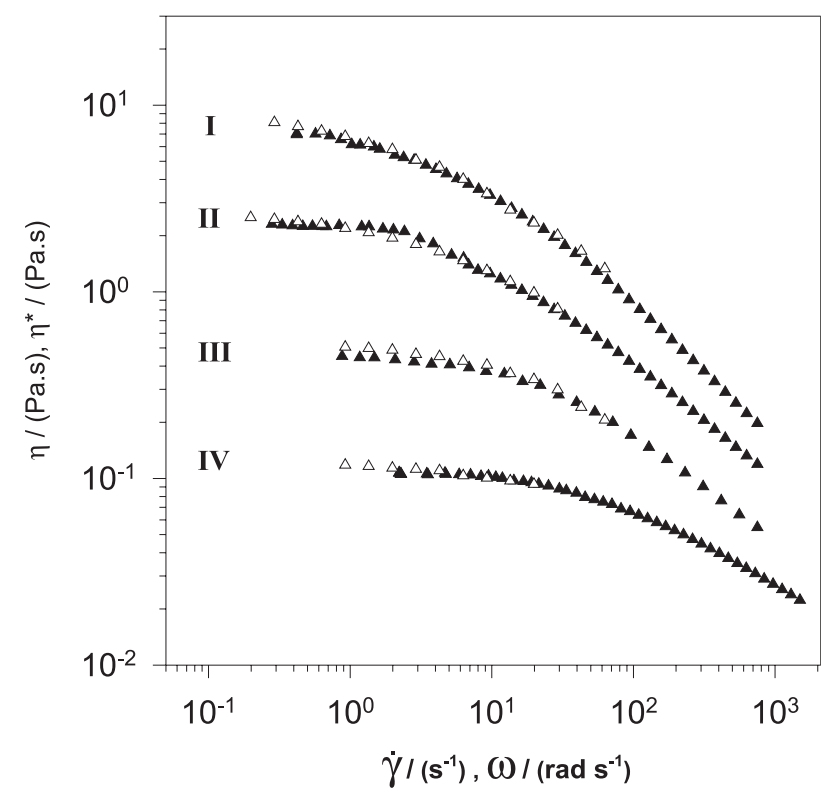

Figure 5. Shear rate $(\dot{\gamma})$ dependence of the viscosity $(\eta)$ and frequency dependence of the complex viscosity $\left(\eta^{*}\right)$ (Cox-Merz plot) for galactomannan solutions in water at $25^{\circ} \mathrm{C}$; GG (curve I, $10 \mathrm{~g} \mathrm{~L}^{-1}$; curve III, $5 \mathrm{~g} \mathrm{~L}^{-1}$ ) and PJ (curve II, $10 \mathrm{~g} \mathrm{~L}^{-1}$; curve IV, $5 \mathrm{~g} \mathrm{~L}^{-1}$ ); $\boldsymbol{\Delta}, \eta ; \triangle, \eta^{*}$ (controlled-stress rheometer).

spectrum remained typical of a macromolecular solution, with a cross-over around $0.2 \mathrm{rad} \mathrm{s}^{-1}$; at higher frequencies, $\mathrm{G}^{\prime}>\mathrm{G}^{\prime \prime}$ and $\mathrm{G}^{\prime}$ reaches a plateau. For the mixed solution, at least for the above composition, no synergy was observed; G' and G' values were even lower than those obtained for $\kappa$-carrageenan alone at $1.0 \mathrm{~g} \mathrm{~L}^{-1}$, throughout the frequency range studied. The fine structure of the PJ galactomannan revealed by ${ }^{13} \mathrm{C}$ NMR, in particular the low probability of unsubstituted D-mannose diads, seems to dictate the disability of this galactomannan to exhibit gelling interactions with $\kappa$-carrageenan.

$\kappa$-carrageenan gels are relatively hazy and brittle and may show the property known as syneresis which is the slow release of water when stored or when frozen and thawed.

Self-supporting gels of $\kappa$-carrageenan and $\kappa$ carrageenan/galactomannan were obtained with higher concentrations of the polymers and $\mathrm{KCl}$. The resulting mixed gels were more transparent than those obtained with $\kappa$-carrageenan alone, and did not present syneresis effects. Table 3 shows the results obtained from compression tests at $25{ }^{\circ} \mathrm{C}$ for $\kappa$-carrageenan at $10 \mathrm{~g} \mathrm{~L}^{-1}$ in $0.25 \mathrm{~mol} \mathrm{~L}^{-1} \mathrm{KCl}$, as well as those obtained for the mixed gels with $\mathrm{PJ}$ and GG galactomannans at different compositions and $10 \mathrm{~g}$ $\mathrm{L}^{-1}$ total polymer concentration. The values determined for the Young's modulus (E) and the elongation at break $\left(\varepsilon_{\max }\right)$ were higher for the pure $\kappa$-carrageenan gel than for the mixed gels. In contrast, for the $\kappa$-carrageenan/PJ galactomannan gels at the mixing ratios of $5: 1$

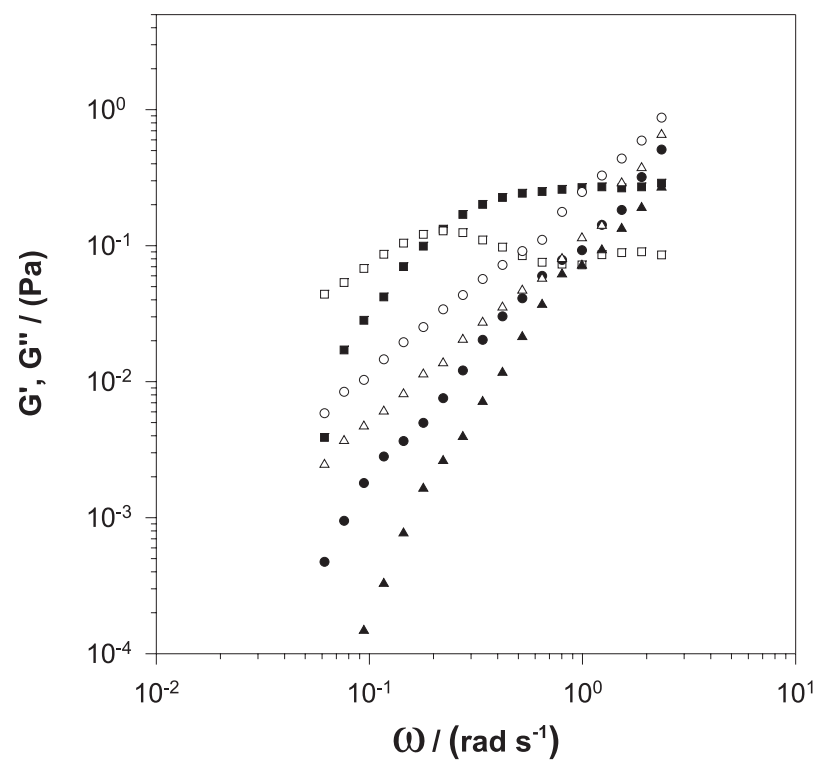

Figure 6. Frequency $(\omega)$ dependence of the dynamic storage $\left(\mathrm{G}^{\prime}\right)$ and loss $\left(\mathrm{G}^{\prime \prime}\right)$ moduli for $\kappa$-carrageenan solutions at $\mathrm{C}=1.0 \mathrm{~g} \mathrm{~L}^{-1}\left(\bullet, \mathrm{G}^{\prime} ; \mathrm{O}\right.$, $\left.\mathrm{G}^{\prime \prime}\right)$ and $\mathrm{C}=1.2 \mathrm{~g} \mathrm{~L}^{-1}\left(\square, \mathrm{G}^{\prime} ; \square, \mathrm{G}^{\prime \prime}\right)$, and for 3:1 k-carrageenan/PJ galactomannan mixed solution at $1.0 \mathrm{~g} \mathrm{~L}^{-1}$ total polymer concentration $\left(\boldsymbol{\Delta}, \mathrm{G}^{\prime} ; \triangle, \mathrm{G}^{\prime \prime}\right)$, in $0.1 \mathrm{~mol} \mathrm{~L}^{-1} \mathrm{KCl}$ at $25^{\circ} \mathrm{C}$ (low shear rheometer).

(maximum), 4:1 and 3:1 and the $\kappa$-carrageenan/GG galactomannan gels at 5:1 and 4:1 (maximum) ratios, the values determined for the stress at break $\left(\sigma_{\max }\right)$ were higher, and therefore the gels are more resistant to rupture than those determined for $\kappa$-carrageenan alone. As the galactomannan composition was increased, the $\sigma_{\max }$ values decreased. Although the synergic effect is not comparable to that observed by several authors for LBG, the addition of PJ or GG galactomannan gives gels significantly stronger than those formed by $\kappa$-carrageenan alone at the same concentrations as in the mixed systems.

Table 3. Parameters obtained from compression tests in $\kappa$-car and $\kappa$-car/ galactomannan $(\mathrm{Gal})$ gels, at $10 \mathrm{~g} \mathrm{~L}^{-1}$ total polymer concentration in 0.25 mol L-1 $\mathrm{KCl}$ at $25^{\circ} \mathrm{C}$

\begin{tabular}{lcccccc}
\hline $\begin{array}{l}\text { Mixing ratio } \\
(\kappa \text {-car:Gal })\end{array}$ & \multicolumn{2}{c}{$\mathrm{E} /\left(10^{4} \mathrm{~Pa}\right)^{\mathrm{a}}$} & \multicolumn{2}{c}{$\sigma_{\max } /\left(10^{4} \mathrm{~Pa}\right)^{\mathrm{b}}$} & \multicolumn{2}{c}{$\varepsilon_{\max } /(\%)^{\mathrm{c}}$} \\
\hline $5: 1$ & $\mathrm{PJ}$ & $\mathrm{GG}$ & $\mathrm{PJ}$ & $\mathrm{GG}$ & $\mathrm{PJ}$ & $\mathrm{GG}$ \\
\hline & 3.2 & 3.8 & 9.0 & 8.9 & 20.9 & 22.5 \\
$4: 1$ & $( \pm 0.18)$ & $( \pm 0.09)$ & $( \pm 0.26)$ & $( \pm 0.15)$ & $( \pm 0.64)$ & $( \pm 0.44)$ \\
& 2.2 & 3.3 & 8.0 & 9.7 & 24.5 & 22.9 \\
$3: 1$ & $( \pm 0.17)$ & $( \pm 0.05)$ & $( \pm 0.46)$ & $( \pm 0.36)$ & $( \pm 1.7)$ & $( \pm 1.06)$ \\
& 2.8 & 2.2 & 7.9 & 5.6 & 18.3 & 21.3 \\
$2: 1$ & $( \pm 0.18)$ & $( \pm 0.25)$ & $( \pm 0.32)$ & $( \pm 0.2)$ & $( \pm 0.22)$ & $( \pm 0.75)$ \\
& 1.8 & 2.2 & 5.9 & 5.6 & 23.2 & 21.7 \\
$1: 1$ & $( \pm 0.08)$ & $( \pm 0.13)$ & $( \pm 0.26)$ & $( \pm 0.38)$ & $( \pm 0.97)$ & $( \pm 0.88)$ \\
& 1.1 & 1.5 & 2.6 & 3.7 & 18.9 & 20.7 \\
$1: 0$ & $( \pm 0.07)( \pm 0.05)$ & $( \pm 0.14)$ & $( \pm 0.06)$ & $( \pm 0.66)$ & $( \pm 1.19)$ \\
& \multicolumn{4}{c}{3.9} & 7.2 & 28.8 \\
& $( \pm 0.06)$ & $( \pm 0.98)$ & $( \pm 0.10)$ \\
\hline
\end{tabular}

${ }^{\mathrm{a}} \mathrm{E}=$ Young's modulus; ${ }^{\mathrm{b}} \sigma_{\max }=$ stress at break; ${ }^{\mathrm{c}} \varepsilon_{\max }=$ elongation at break 


\section{Conclusions}

Some structural and solution properties of Prosopis juliflora seed gum and guar gum were compared. High resolution ${ }^{13} \mathrm{C}$ NMR showed differences in the diad sequencies, in particular the lower probability of finding totally unsubstituted diads in the PJ galactomannan. Nevertheless, the results obtained from viscosity and viscoelastic measurements revealed similar solution properties for the gums. No synergic effect was observed in the viscoelastic behaviour of $\kappa$-carrageenan/PJ galactomannan in $0.1 \mathrm{~mol} \mathrm{~L}^{-1} \mathrm{KCl}$ at $1.0 \mathrm{~g} \mathrm{~L}^{-1}$ total polymer concentration. Considering the relatively slight differences in the $\mathrm{M} / \mathrm{G}$ ratio, intrinsic viscosity and consequently molecular weight between the galactomannas, mixed gels of PJ with $\kappa$-carrageenan were expected to give similar effects to those observed for GG mixed gels. Selfsupporting gels resulting from the addition of PJ and GG galactomannans to $\kappa$-carragenan displayed similar mechanical properties, despite their differences in fine structure. The results show that Prosopis juliflora seed gum possesses functional properties that are similar to those of guar gum, and consequently, could be used as an alternative gum for industrial applications.

\section{Acknowledgments}

The authors thank CNPq, CAPES, FAPERJ and FUJB for financial support.

\section{References}

1. McCleary, B. V.; Clark, A. H.; Dea, I. C. M.; Rees, D. A.; Carbohydr. Res. 1985, 139, 237.

2. Dea, I. C. M.; Morrison, A. In Advanced in Carbohydrate Chemistry and Biochemistry; Tipson, R. S.; Horton, D., eds.; Academic Press: New York, 1975, vol. 31, p. 241.
3. Dea, I. C. M.; Morris, E. R.; Rees, D. A.; Welsh, E. J.; Barnes, H. A.; Price, J.; Carbohydr. Res. 1977, 57, 249.

4. Morris, E. R.; Rees, D. A.; Young, G.; Walkinshaw, M. D.; Darke, A.; J. Mol. Biol. 1977, 110, 1.

5. Dea, I. C. M.; McKinnon, A. A.; Rees, D. A.; J. Mol. Biol. 1972, 68, 153.

6. Rees, D. A.; Biochem. J. 1972, 126, 257.

7. Morris, E. R.; Rees, D. A.; Robinson, G.; Young, G. A.; J. Mol. Biol. 1980, 138, 363.

8. Tako, M.; Nakamura, S.; Carbohydr. Res. 1985, 138, 207.

9. Lopes, L.; Andrade, C. T.; Milas, M.; Rinaudo, M.; Carbohydr. Polym. 1992, 17, 121.

10. Schorsch, C.; Garnier, C.; Doublier, J.-L.; Carbohydr. Polym. 1997, 34,165.

11. Pai, V. B.; Khan, S. A.; Carbohydr. Polym. 2002, 49, 207.

12. Fernandes, P. B.; Gonçalves, M. P.; Doublier, J.-L.; Carbohydr. Polym. 1992, 19, 261.

13. Garcia, R.G.; Andrade, C. T.; Carbohydr. Polym. 1997, 34, 157.

14. Cruz, G.; Ph. D. Thesis, ETH, Zurich, 1999.

15. Figueiredo, A. A.; Food Technol. 1990, 44, 118.

16. Andrade, C. T.; Azero, E. G.; Luciano, L.; Gonçalves, M. P.; Int. J. Biol. Macromol. 2000, 27, 349.

17. Doublier, J.-L.; Launay, B. J.; J. Text. Struct. 1981, 12, 151.

18. Gaisford, S. E.; Harding, S. E.; Mitchell, J. R.; Bradley, T. D.; Carbohydr. Polym. 1986, 6, 423.

19. Grasdalen, H.; Painter, T.; Carbohydr. Res. 1980, 81, 59.

20. Boziek, S. M.; Izzard, M. I.; Morrison, A.; Welti, D.; Carbohydr. Res. 1981, 93, 279.

21. Manzi, A. E.; Cerezo, A. S.; Schoolery, J. N.; Carbohydr. Res. 1986, 148, 189.

22. Joshi, H.; Kapoor, V. P.; Carbohydr. Res. 2003, 338, 1907.

23. Brummer, Y.; Cui, W.; Wang, Q.; Food Hydrocolloids 2003, 17, 229.

24. Cox, W. P.; Merz, E. H.; J. Polym. Sci. 1958, 28, 619.

25. Andrade, C. T.; Azero, E. G.; Luciano, L.; Gonçalves, M. P.; Int. J. Biol. Macromol. 1999, 26, 181.

Received: January 26, 2006

Published on the web: June 12, 2006 